\title{
The Labor Market in Poland and the Social Responsibility of the State and Business: Comparative Aspects
}

\author{
Anna Krajewska (iD) https://orcid.org/0000-0001-8895-6397 \\ Ph.D., Full Professor at the Warsaw University of Technology \\ College of Economics and Social Sciences, Warsaw, Poland \\ e-mail: anna.krajewska@pw.edu.pl
}

\section{Stefan Krajewski}

Ph.D., Full Professor at the Warsaw University of Technology

College of Economics and Social Sciences, Warsaw, Poland

e-mail: stefan.krajewski@pw.edu.pl

\section{Abstract}

Since the beginning of the transformation of the Polish economy, Many disturbing phenomena have appeared on the labour market in Poland. This paper points out to several of them, namely: 1 ) inconsistency in respecting the rules of the market mechanism and the important role of political decisions, 2) long-term persistence of high unemployment rate and low effectiveness of methods of combating unemployment, 3) low wages and rising income diversification, 4) high share of non-standard forms of employment in total employment. The scale of these disturbing phenomena is bigger than in other economies under transformation.

In response to the imperfections of the market, many publications concerning corporate social responsibility appeared in Poland. According to the authors the reasons for the shortcomings of the labour market discussed in the paper should, however, be sought not only in the non-respect of the principles of corporate social responsibility, but also in the weaknesses of the adopted systemic solutions and weaknesses of institutions of the State.

Keywords: labour market, transition of the economy, Corporate Social Responsibility JEL: J01, J08, P20 


\section{Introduction}

Many phenomena appeared on the labor market during the transformation of the Polish economy, and they are often viewed negatively from a social and ethical point of view. The most important examples of non-compliance with the principles of ethics and corporate social responsibility include the striking inconsistency in respecting the rules of the market mechanism, how political decisions affect various sectors of the economy, the low effectiveness of attempts to combat unemployment and its negative effects, low wages and increasing income disparities, as well as the high proportion of non-standard forms of employment.

This article attempts to verify the hypothesis that the main causes of the negative phenomena observed on the labor market were the liberal economic policy, the weakening of the position of trade unions, and the large role of the shadow economy, the development of which was fostered by the high unemployment rate and lack of consistency in respecting the law and the labor code.

\section{The essence of the labor market}

There are many reasons why the labor market should be treated differently than the market for goods and services and the capital market. First of all, the market mechanism works effectively under conditions of perfect competition. However, the labor market is clearly different from other markets, because:

1. It shows more imperfections than other markets - there are more employees than employers, but employers have more bargaining power and can impose their conditions on employees.

2. Labor mobility is smaller than the mobility of capital.

3. Employees are more dispersed and have less access to information than employers.

4. The social, political, and economic effects of imbalances in the labor market are much more serious than in other markets (high unemployment, low wages) and threaten the collapse of social order.

The market's ability to operate effectively and create a strong motivation to increase professional activity, entrepreneurship, and take risky actions is its important advantage. This leads to a better use of production factors and an increase in entrepreneurs' income. At the same time, however, less enterprising entities go bankrupt and fall out of the market, and some employees lose their jobs. The diversity of income and assets resulting from the play of market forces may be treated as unfair and socially unacceptable, and lead to frustration, anxiety, and protests of wider social groups, and the intensification of other negative social and political phenomena.

In this situation, the state should play an important role in influencing the functioning of the labor market. In the literature (Bolero et al. 2003), there is a consensus that the state's influence on the labor market should involve: 
1. Preventing discrimination of employees and preventing poverty.

2. Regulating employment contracts and the rights and obligations of employees and employers, and, in particular, respecting labor law provisions.

3. Regulating the activities of trade unions and employers' associations and acting as arbiter in the event of conflicts.

4. Providing social security in the event of unemployment, old age, illness, and death.

This means that the situation on the labor market should be determined not only by economic efficiency but also by ethical considerations. This is also the opinion of the European Commission (Gasparski et al. 2019), which recommends that ethics and social responsibility should become an integral part of management and be present in everyday business operations. The Commission postulates that ethics and corporate social responsibility should be applied in enterprises, respected by public authorities, and be the subject of academic research.

For many years, there has been rich literature in Poland regarding business ethics and corporate social responsibility (e.g., Gasparski 1999; Gasparski, Lewicka-Strzelecka 2001; Filek 2006; Klimczak, Lewicka-Strzelecka 2007), and also economic ethics (Klimczak 2006). In turn, they treat the ethics of the state as a concept referring to ancient and medieval philosophy, and especially to Aristotle's views. Synthetically, this concept was characterized by the contemporary German philosopher Otfried Höffe (1993), who stated: "The guiding idea of the state and of the law is the idea of justice" (quoted in Stawrowski 2019). In the common understanding, this thought means that "the object of ethics is to describe economic phenomena from the point of view of ethical values in the scale of the entire economic system. At this level, the issue of the ethical dimension of social policy as well as culture (social inequalities, corruption, bribery) is also important" (Prochownik, Rogowicz, Paletko 2019).

\section{Examples of unethical actions in the transformation process of the Polish economy}

\section{The lack of consistency in the observance of market economy rules - the weak lose and the politically strong strengthen their position}

The marketization of the economy has run inconsistently in Poland. In practice, it turned out that political decisions played a big role, which had an impact on the labor market. Two extreme cases demonstrate this: The political decisions to eliminate state-owned farms (PGRs) and protect jobs in mining, which are economically unjustified.

The government was planning to eliminate state-owned farms back in 1990 . It turned out, however, that PGRs were not owners of the land, and a separate act had to be prepared, which was approved in 1991. I agree with the opinion of Adam 
Tański, the then Minister of Agriculture, who said that "in a collision with the realities of the free market, PGRs showed their helplessness, without permanent subsidies from the budget they could not exist" (Nie zamordowałem pegeerów 2014); these farms were unable to finance their expenses, and they were threatened with bankruptcy. However, one-third of these farms functioned efficiently. Why, then, were all of them eliminated? Why were those that were threatened not given a chance to restructure? Where did this rush come from? Maybe PGRs should have been forced to restructure, and only after 2-3 years make the final decisions. In 1990, subsidies to agriculture accounted for $10.2 \%$ of the object subsidies, which constituted $5.9 \%$ of total subsidies and a mere $0.58 \%$ of current state budget expenditure (Statistical Yearbook 1994, pp. 155-156). Therefore, they were not amounts that would have seriously undermined the state's finances.

In 1991, over 330,000 people were employed in state-owned farms, which, together with families, accounted for about 1.5 million people condemned to an uncertain existence. The then decision-makers emphasized that people from former state-owned farms were protected - they received benefits, their children received scholarships, and it was possible to buy apartments cheaply (which, as it turned out, urgently required repairs and could not be sold because they were in remote areas; hence, you could not get to work due to the lack of train or bus connections). The benefits were quickly spent on TVs, carpets, and motorcycles. Is it any wonder that these people did not think about the future? Probably not. At that time, even many directors of large state-owned enterprises did not think that the process of marketization of the economy was irreversible. So, can we bear a grudge against people with less social awareness and who were less informed?

The fact that the consequences of the decision to eliminated state-owned farms are long-lasting has been confirmed not only by the research (Litwiński, Sztanderska, Giza-Poleszczuk 2008), which indicates that enclaves of poverty pass from generation to generation, but also the high unemployment rate in the poviats with former PGRs. Even years later, at the end of 2017, with an average unemployment rate of $6.6 \%$, in several poviats of the Warmian-Masurian Voivodeship, it was close to $20 \%$, e.g., in Braniewo - 21.1\%, Kętrzyń - 17.9\%, and Węgorzewo - 18.4\%, www.stat.gov.pl (accessed: 20.10 .2018$)$.

The consistent subsidization of hard coal mining throughout the transformation period is, however, a political derogation from the rules of liberalism. In communist Poland, mining was particularly preferred due to the high internal demand for coal resulting from fast industrialization. Moreover, coal was an important item in Polish exports. Workers for the mining industry were therefore drawn from all over Poland and were generously remunerated. Miners, using their strong position in the labor market, won a lot of additional privileges, which they still do not want to give up.

The main purpose of the so-called shock therapy was to quickly heal the economy by eliminating unprofitable enterprises. This was to lead to the reduction of object subsidies, which would seriously affect the reduction of public expenditure, and thus would en- 
able tax reduction. Indeed, subsidies to enterprises were decreasing, but this rule, in principle, did not apply to hard coal mining. ${ }^{1}$ Although PGRs and other unprofitable enterprises were quickly eliminated, the hard coal and lignite mining section recorded a record loss of over PLN 4.5 billion in 2015 (Central Statistical Office 2018, p. 587). Whether it affected the level of remuneration in mining is shown by the data in Table 1. Before the transformation, wages in mining exceeded twice the average wage. In 1990, the relationship between the average wage and the salaries of miners underwent a slight decline, but they quickly returned to the situation recorded before the transformation, despite the deficit recorded in the sector. This happens in mining, while the level of wages in the textile, clothing, and leather industries has sharply declined (although deep restructuring has been carried out there, and these industries now have good financial results).

Table 1. Relationship between wages in selected industries (average salary =100)

\begin{tabular}{|l|r|r|r|r|r|c|}
\hline \multicolumn{1}{|c|}{ Industry } & 1985 & 1989 & 1990 & 1993 & 2014 & 2017 \\
\hline Coal mining & 215.5 & 182.2 & 160.9 & 182.3 & 188.8 & $170.0^{\text {a) }}$ \\
\hline Textile & 95.5 & 97.5 & 84.9 & 78.3 & 68.5 & $73.2^{\text {b) }}$ \\
\hline Clothing & 86.0 & 86.1 & 75.6 & 73.0 & 54.1 & 57.6 \\
\hline Leather & 91.0 & 91.3 & 77.7 & 70.8 & 60.4 & 63.6 \\
\hline
\end{tabular}

a) Hard and brown coal mining (lignite)

b) Production of textile products

Source: Author's own calculations based on Statistical Yearbooks, Central Statistical Office (GUS),

Warsaw 1991, pp. 231, 232 and 1994, p. 214 and Statistical Yearbook of the Republic of Poland, Central Statistical Office (GUS), Warsaw 2015, pp. 273; 2018, p. 275.

Observing the remuneration relationship raises numerous questions. Can the level of remuneration be completely detached from the financial condition of the company? Can high wages in mining be explained by the strenuous work and high degree of danger?

It is true that the work of a miner is difficult and dangerous. However, the Central Statistical Office data on accidents at work indicate that working in agriculture, the fishing industry, and construction, and even in transport and storage, is also very dangerous. ${ }^{2}$ The salaries in these sections are, however, much lower. Or maybe such large

1 In 1989, the object subsidies accounted for $26.9 \%$ of current expenditure of the state budget. In subsequent years, they began to decline rapidly to 9.4\% (1990), 4.1\% (1991) and 1.5\% (1992). The structure of object subsidies also seriously changed. In 1991 as much as $53 \%$ of these subsidies were for coal, and second place was occupied by subsidies for PKP rail transport $-21.4 \%$, and PKS bus transport - 9.7\% (Statistical Yearbook 1991, pp. 147, 1992, p. 140). In 1992, the weight of object subsidies shifted to PKP (47.2\%) and PKS (22.7\%), while $14.2 \%$ was allocated to mining. Since 1993, mining has received subject subsidies to restructur the sector instead of object subsidies (Statistical Yearbook 1994, p. 156).

2 In 2014, in mining there were 14 people injured in accidents at work per 1000 employees, including 0.15 fatal accidents. At the same time in agriculture, forestry, hunting, and fishing this indicator was 11 people (including 0.092 , or about 0.1 fatalities). In construction, transport, and warehousing, these indicators were respectively: 8 and $8.5 \%$ of people and 0.067 and 0.057 per 1000 employees (GUS, Statistical Yearbook of Labor 2015, p. 250). 
wage differences can be explained by the small supply of labor and the lack of people willing to work in mining? Press releases describing the situation in mining show that due to the high level of earnings, there are a lot of people willing to work in mining, including underground. However, without connections or the support of trade unions, getting a job in mines is practically impossible (Baca-Pogorzelska 2016).

Another argument showing that the high level of remuneration in mining does not result from the situation on the labor market but from the strong political position of the mining unions is the data on the relationship between labor costs in mining and other sectors of the economy in Poland and other countries (Table 2). In 2016 (in comparison with 2012), these relationships underwent very moderate changes. Still, the relationship between hourly labor cost per employee in mining and industrial processing remains the biggest in Poland. Due to the fact that remuneration constitutes the main element of labor costs, it can be seen that wage the privileges of the Polish mining industry clearly differ from the standards adopted in other European Union countries.

Table 2. The relationship between hourly labor costs per employee in EU countries in selected sections in 2012 and 2016 (Industrial processing = 100)

\begin{tabular}{|l|r|r|r|r|r|r|}
\hline \multirow{2}{*}{\begin{tabular}{c} 
Country \\
\cline { 2 - 7 }
\end{tabular}} & \multicolumn{2}{c|}{$\begin{array}{c}\text { Mining } \\
\text { and extraction }\end{array}$} & $\begin{array}{c}\text { Production } \\
\text { and supplies } \\
\text { of electricity, gas, } \\
\text { and water }\end{array}$ & \multicolumn{2}{c|}{ Construction } \\
\cline { 2 - 7 } & 2012 & 2016 & 2012 & 2016 & 2012 & 2016 \\
\hline Austria & 114.3 & 114.1 & 144.4 & 138.9 & 89.3 & 89.3 \\
\hline Belgium & 109.7 & 109.7 & 166.2 & 165.1 & 80.0 & 79.4 \\
\hline Czech Republic & 140.6 & 123.8 & 174.7 & 162.4 & 68.6 & 93.1 \\
\hline France & 94.2 & 89.9 & 154.7 & 152.9 & 86.3 & 83.5 \\
\hline Spain & 124.8 & 142.3 & 217.2 & 206.2 & 93.0 & 88.5 \\
\hline Germany & 116.4 & 114.2 & 136.3 & 126.6 & 73.1 & 70.0 \\
\hline Poland & 213.9 & 180.6 & 182.3 & 176.6 & 100.6 & 98.7 \\
\hline Slovenia & 141.3 & 113.2 & 159.8 & 160.4 & 82.3 & 87.7 \\
\hline Sweden & 116.7 & 120.5 & 120.8 & 122.0 & 92.6 & 95.2 \\
\hline
\end{tabular}

Source: Author's own compilation based on the Statistical Yearbook of Labor, Central Statistical Office (GUS), Warsaw 2015, p. 356; 2017, p. 350.

\section{Unemployment}

Shock therapy in Poland was the most successful attempt to use the so-called Washington Consensus, which assumed that economic policy should be based on privatization, liberalization, deregulation, and tough fiscal policy (Williamson 1993). As a result of the privatization of large state enterprises carried out at a rapid pace, many employees lost their jobs, often under so-called group layoffs and early retirement. The liberalization of foreign trade, the collapse of trade with the Comecon countries, especially with the former USSR, as well as the pursuit of a conscious policy that led 
to the bankruptcy of state-owned enterprises, ${ }^{3}$ was another reason for the surge in unemployment.

In the initial period of the transformation, unemployment grew rapidly. In the first quarter of 1990, unemployment stood at 266,000, and the registered unemployment rate was $1.5 \%$. In the fourth quarter of that year, the number of unemployed exceeded 1 million $(1,126,100)$, and the unemployment rate had risen to $6.3 \%$. In the fourth quarter of 1993, unemployment reached almost 3 million $(2,889,600)$, and the unemployment rate had increased to $16.4 \%$. The percentage of unemployed people dismissed due to reasons related to the workplace, i.e., group layoffs, increased rapidly - from $5.7 \%$ in the first quarter of 1990 to $19.5 \%$ in the fourth quarter of 1993, although the maximum level of group layoffs, which reached $24.1 \%$, was recorded in the second quarter of 1992 (Statistical Yearbook 1994, p. 129). The situation on the labor market did not improve significantly until 2017. It resulted mainly from the upturn in Poland and the world. The unemployment rate was down to $4.9 \%$, the lowest in 25 years. This is a great reason to be proud. However, it should be remembered that in some EU countries, the unemployment rate was lower, for example, $2.9 \%$ in the Czech Republic, 3.8\% in Germany, 4.2\% in Hungary, and $4.4 \%$ in the United Kingdom (Statistical Yearbook of Poland 2018, p. 796).

It is worth noting that in Western Europe, the fight against unemployment is seen as a government priority. In Poland, however, unemployment was seen as the "necessary evil" and the price to be paid for switching from a centrally planned economy to a market economy. And this was manifested by the fact that unemployment benefits were low and short-paid, and that very modest funds were spent on active forms of combating unemployment.

Poland is one of the few OECD countries in which the period of collecting unemployment benefits has been shortened in recent years from 18 to 12 months while in some countries it lasts for 3-4 years, and the amount of benefits in relation to the salary paid during work is also very low. For example, from March 1, 2019, the basic benefit is PLN 847 in the first 20 days of entitlement to unemployment benefit and PLN 665.70 in the subsequent days. ${ }^{4}$ In many OECD countries, the amount of benefit depends on previous earnings and amounts to as much as $70-80 \%$ of the salary (Kubiak, Kwiatkowski 2017, pp. 198-202). It is also worth stressing that although the hypothesis is put forward in the literature that generous benefits increase unemployment and intensify wage pressure (Snower 1997), in the economic policy of Western European countries, ethical and solidarity considerations play a greater role than a purely

3 Apart from income tax, state-owned enterprises were subject to excessive wage growth tax and an obligatory dividend from the initial capital, even when the enterprise incurred losses. The very high interest rate on loans taken out before the transformation was another reason for the deterioration in the financial standing of enterprises.

4 The amount of the benefit depends on the seniority and is: up to 5 years of work - $80 \%$ of the basic benefit, over 5 years, but not more than 20 years $-100 \%$ of the basic benefit, and in the case of a seniority of more than 20 years $-120 \%$ of the basic benefit, http://mupplock.praca.gov.pl/ rynek-praca/stawki-kwoty-wskaźniki (accessed: 6.03.2019). 
economic calculation. The low effectiveness of the fight against unemployment also results from the lack of funds financed from the Labor Fund and how they are distributed. For example, according to GUS data, in 2014, nearly PLN 3 billion was allocated to unemployment benefits, which is more than was spent for active forms of the fight against unemployment in the form of training, intervention works, public works, loans, and vocational training for young people - for which approximately PLN 1.8 billion was spent in total (Statistical Yearbook of Labor 2015, p. 175).

\section{Low wages and growing income diversification}

In the initial period of the transformation, low wages in Poland were widely regarded positively, arguing that they contribute to improving the competitiveness of enterprises on foreign markets, they are an important factor accelerating the inflow of foreign capital, and they also favor the development of small enterprises. Only recently has there been a discussion on whether the low level of remuneration in Poland is justified by the economic situation of the country and what the consequences are thereof (Krajewska 2018, pp. 73-90).

The following information proves that changes in the level and relationship of wages in Poland are heading in a dangerous direction.

The low share of employment-related costs in GDP and, furthermore, its clearly declining trend arouses anxiety. Table 3 includes EU countries with the highest and the lowest share of these costs in GDP. In 2017, labor-related costs in Poland accounted for $38.6 \%$ of GDP. A lower share was recorded only in three EU countries. Over the past quarter of a century, this rate has decreased in Poland by 4.3 percentage points. It is also worth noting that in some countries, the share of costs related to employment is even above $50 \%$ of GDP and is characterized by quite high stability in the long run.

Various studies (Kabaj 2013; Majchrowska 2016; Rutkowski 2016) show that the growth rate of labor productivity in Poland is higher than the rate of wage growth, and the disproportions in Poland are bigger than in other countries. For example, taking into account relative values, labor productivity in Poland in 2014 was lower by $32 \%$ than in the EU-15, and wages by $45 \%$ (Majchrowska 2016, p. 20). It is also worth quoting the calculations by Kabaj (2013), which show that if between 2001 and 2012 wages had increased at the same rate as labor productivity, in 2012, the average wage would be higher by PLN 1,628 and would amount to PLN 5,150 instead of PLN 3,522.

The high share of employees receiving low wages, i.e., up to $50 \%$ of the average wage in the economy. It stood at $13.4 \%$ in $1999,18.9 \%$ in 2012, and $19.0 \%$ in 2014 (Statistical Yearbook of Labor 2015, p. 306). It is only in 2016 that we see a slight decline to $17.5 \%$ (Statistical Yearbook of the Republic of Poland 2018, p. 276). This means that almost every fifth employee receives half of the average salary. In 2014, in this category (Statistical Yearbook of Labor 2015, pp. 306-310), there were not only employees performing simple work (43.1\%), but also members of such professional groups as technicians and 
other medium personnel (10.1\%), office workers (16.5\%), service and sales staff (48.1\%), industrial workers and craftsmen $(25.4 \%)$, and operators and assemblers of machines and equipment (19.9\%.)

Table 3. The share of employment-related costs in GDP in selected EU countries

\begin{tabular}{|l|c|c|c|c|c|c|}
\hline \multicolumn{1}{|c|}{ Country } & 1990 & 1995 & 2000 & 2005 & 2010 & 2017 \\
\hline France & 52.4 & 51.5 & 51.2 & 51.0 & 52.1 & 52.2 \\
\hline Denmark & 55.5 & 52.7 & 53.2 & 50.5 & 53.0 & 51.8 \\
\hline Germany & 56.0 & 54.0 & 53.4 & 49.8 & 49.7 & 50.9 \\
\hline$\ldots$ & $\ldots$ & $\ldots$ & $\ldots$ & $\ldots$ & $\ldots$ & $\ldots$ \\
\hline Poland & 42.9 & 40.9 & 41.3 & 36.7 & 37.9 & 38.6 \\
\hline Romania & 51.6 & 34.0 & 39.5. & 38.9 & 35.5 & 36.0 \\
\hline Greece & 32.3 & 32.3 & 33.6 & 34.3 & 35.8 & 33.6 \\
\hline Ireland & 46.3 & 41.1 & 39.9 & 39.0 & 41.3 & 29.4 \\
\hline
\end{tabular}

Source: Statistical Yearbook of the Republic of Poland, Central Statistical Office (GUS), Warsaw 2001, p. 720; 2005, p. 871; 2015, p. 884; 2018, p. 890.

And it is worth recalling that the minimum wage of $50 \%$ of the average salary was accepted by the ILO (Convention No. 137 of 1970). This minimum wage level was also provided in the European Social Charter. At the same time, however, it appears from press releases and reports of joint-stock companies that the remuneration of Polish CEOs and outstanding specialists was equal to, and may have even exceeded, the remuneration in many countries of Western Europe.

In Poland, in comparison with other EU countries, the share of low-wage employees is high, i.e., those earning no more than two-thirds of the national median of hourly earnings. In 2014, low-paid employees accounted for $23.6 \%$ of all employees. With an average of $17.2 \%$ for the EU-28, a higher share of this indicator was observed only in three countries - Latvia (25.5\%), Romania (23.6\%), and Lithuania (24.0\%). By contrast, low-paid workers accounted for only 2.6\% in Sweden, 3.8\% in Belgium, 5.3\% in Finland, 8.6\% in Denmark, and 8.8\% in France (Wages and labor costs, http:// eurostat.eurostat.statistics-explained.ec.europa.eu, accessed: 22.02.2019).

Poland falls in the OECD ranking on the quality of work. In terms of earnings (low and burdened with inequalities), Poland ranks 32nd among OECD countries. Only Chile and Mexico were behind us (OECD Employment Outlook 2015).

The data indicate an increase in income inequalities in Poland. The phenomenon is recognized (Skidelsky 2012, p. 159) as unfavorable for two reasons. Firstly, equality is regarded as a good in itself (the welfare state is part of a developed economy), and secondly, inequalities, especially rapidly growing ones, lead to political instability. 


\section{Non-standard forms of employment}

Due to the excessive flexibility of the labor market, weak trade unions, high unemployment which has lasted for a long time, and the acquiescence to the functioning of and the development of the shadow economy, labor law is not respected in Poland. This is reflected by a very high percentage of people working on non-standard forms of employment contracts, i.e., fixed-term contracts, occasional, in the form of self-employment, or in the gray zone. Eurostat data show that in 2017, in Poland, 26.1\% of employed people worked on fixed-term contracts, compared to the EU average of $14.3 \%$. Only Spain $(26.8 \%)$ was in a worse situation than Poland, while in some countries fixed-term contracts played a negligible role, accounting for $1.2 \%$ of employment contracts in Romania, 1.7\% in Latvia, 3\% in Lithuania, 3.1\% in Estonia and 4.4\% in Bulgaria (Rozwadowska 2018). Moreover, Poland was in the group of countries in which the share of temporary employment in total employment grew rapidly (in 2002 it amounted to $15.4 \%$ ), and to a large extent, it included young people (aged 15-24). In 2015, this concerned $71.2 \%$ of young employees. Only in Slovenia $(72.7 \%)$ was the situation worse, while in Estonia, $11.2 \%$ of young workers were in such a situation, and in the UK 6.2\%, with an OECD average of 24.1\% (OECD 2015).

The rapidly growing share of temporary contracts, and especially of civil-legal contracts, is an extreme' phenomenon that proves that employers do not comply with the labor code. ${ }^{5}$ These contracts are detrimental to employees because, apart from uncertainty and instability of work, they do not give the right to leave of absence, medical care, protection related to parenthood, retirement, or creditworthiness. However, they are clearly preferred by employers, because they involve easier dismissals, there is no need to pay compensation in the event of unjustified dismissals, lower labor costs (lower social security contributions, lower costs of training, holidays, etc.), and a greater possibility of non-compliance with rules regarding working time and health and safety conditions.

Another manifestation of the deregulation of the labor market in Poland involves people defined for tax purposes as self-employed. According to GUS estimates (2018), in 2016, there were 1.15 million natural persons who carried out non-agricultural activities without employing employees on the basis of an employment relationship, and thus they had the status of self-employed. Turning to self-employment is favored by the tax solutions adopted in Poland. Such people do not have to settle income tax according to progressive rates, and in addition, they pay lower social security contributions. The self-employed group is very diverse. There are people with very low incomes, unskilled people, those running a simple business (cleaners, security guards),

5 The results of inspections by the National Labor Inspectorate (PIP) show that $26.7 \%$ of the examined civil law contracts had characteristics of a contract of employment, the price was the decisive criterion in over $80 \%$ of public tenders, which resulted in companies which did not employ full-time employees and which paid very low wages being awarded public procurement contracts. Health and safety requirements are often not observed, especially in SMEs (Szumilewicz 2018). 
people "pushed" by companies into self-employment to save on labor costs, as well as outstanding, high-class managers, lawyers, athletes, artists, and journalists who, acting in accordance with the law, pay $19 \%$ tax on their very high income. They act in accordance with the law. However, is this action ethical? Should it be maintained, only because once, on the tide of extremely liberal views, were such provisions introduced? How does this relate to ethics and corporate social responsibility?

\section{The causes and consequences of behaviors on the labor market which do not respect ethics and corporate social responsibility}

The word ethics, in the literal translation from the Greek, meaning "custom," refers to the course of action approved and accepted in society. In the ordinary sense, ethical behavior is a behavior that is righteous, just, and fair. Thus, the examples of irregularities in the labor market in Poland cited above should be considered unethical. Many of these irregularities are a consequence of the socio-economic system adopted in Poland and the institutional solutions adopted in the initial period of transformation.

The shape and problems of the current labor market were strongly influenced by the shock therapy used in the initial period of the transformation, followed by a variant of the liberal policy, which clearly preferred entrepreneurs, implemented by successive governments. Further years of the transformation were also under the slogan of market glorification. And although there are many participants on the market - consumers, employees, and entrepreneurs - it was decided to pursue economic policy clearly set out to create favorable conditions for entrepreneurs. In practice, this was reflected in taking measures to weaken the position of trade unions, reduce taxes for entrepreneurs, reduce labor costs, make the labor market more flexible, reduce the scope of social benefits and tolerate the vast gray zone. The spread of unethical activities on the labor market was largely fostered by a high unemployment level, especially in the regional cross-section and among low-skilled people.

Accurately, though bluntly, the problems of the transformation of the Polish economy were summarized by Tadeusz Kowalik (2008, p. 34), who indicated social weaknesses (unemployment, low benefits, and low salary not keeping up with the increase in labor productivity), writing: "All these long-lasting persistent peculiarities, though intense to a different degree, prompted me to express ten years ago ${ }^{6}$ that as a result of the epigonic-bourgeois revolution in Poland, one of the most unjust socio-economic systems of Europe of the second half of the twentieth century was created. The further course of events strengthens me in this belief." Another decade has passed, and the above opin-

6 The author refers to his earlier article: T. Kowalik, Sierpień - epigońska rewolucja mieszczańska, "Nowe Życie Gospodarcze" 1996, No. 37. 
ion is still valid. Neither the 500+ Program nor raising the minimum wage has solved the problem. Unemployment benefits are still very low, non-standard ("junk") employment contracts persist, and tax policy requires major changes. ${ }^{7}$

Various irregularities in the labor market may result from maintaining a balance between the two main players on the labor market - employers and employees. The most important task of trade unions is to guard the interests of employees and prevent their discrimination and unfair treatment. However, since the beginning of the transformation, trade unions have not had good public relations in Poland, neither in the media nor among employers. It is often indicated that they act destructively, exhibit demanding attitudes, burden employers with additional costs related to maintaining trade union posts, expenditures on trade union infrastructure (e.g., rooms), and they also force employers to agree to maintain workers protected against dismissal.

Trade unions in Poland are weak for two reasons: the low degree of unionization, and the low effectiveness in negotiations with employers and the government on issues concerning all employees. It is estimated that in Poland, approx. 1.6 million people belong to trade unions, which is about $11-12 \%$ of the total number of employees. By comparison, in 1990, about $40 \%$ of employees belonged to the unions. The OECD data shows that the unionization rate is similar to that in the US but much lower than in Western European countries, where the degree of unionization is also falling. In Sweden, over a decade ago, over $90 \%$ of employees belonged to trade unions, while currently, it is about 70\%. The other Scandinavian countries and Luxembourg are still characterized by high unionization (above 60\%) https://stats.oecd.org (accessed: 12.01.2017).

In Poland, the largest degree of unionization is in large state enterprises, mainly those in traditional branches of industry (the strongest is in mining) and in the public sector (where the teaching unions are the strongest). The private sector accounts for about $30 \%$ of trade union members. They are mainly concentrated in large privatized companies with foreign capital.

According to the research conducted by Juliusz Gardowski (2013), trade unions are effective when: 1) the union's management is competent in labor and trade union law, as well as business economics, 2) unions represent more than half of the employees, 3) the number of unions in one enterprise does not exceed three, and optimally two unions, 4) the management of the unions cooperates with the management board permanently in the area of employee affairs, 5) relations with the management board are relatively peaceful. Unfortunately, in Polish enterprises, these conditions will probably not be met quickly. This is indicated by, among others, research on the liberalization of labor markets (Filipowicz et al. 2017, pp. 234-240), which shows that Poland is among the OECD countries with the highest synthetic index of liberalization (next to Great Britain, the USA, Korea, and Estonia). This indicator included three varia-

7 The main shortcomings of labor taxation are the high bottom tax rate, low tax-free income and high social security contributions. 
bles: the degree of unionization, the relationship between the minimum wage and the median, and the replacement rate.

The increase in the size of the shadow economy in Poland was the natural consequence of the weak position of trade unions, high unemployment, and the government's lack of consistency in respecting the provisions of the law and the labor code.

The size of the shadow economy in Poland is estimated differently: from $21 \%$ of GDP, according to the FOR (Shadow Economies 2015) report, to 22.1\% of GDP, indicated by eminent gray zone researchers (Schneider 2018). International research (Schneider 2009, p. 44) indicates that high taxes and social security contributions affect the growth of the gray economy in the labor market to the greatest extent (35-38\% of indications). Tax morality also plays a significant role (22-25\%), followed by factors such as the quality of government institutions (10-22\%), labor market regulations (7-9 \%), payment method (5-7\%), and quality of public services (5-7\%). High social security contributions in Poland are also given as the main reason for the escape of some entrepreneurs to the gray zone (Wyrzykowski 2013, p. 192). They are also an excuse for tolerance towards the gray economy.

The high level of labor market liberalization, weak trade unions, and the large gray zone area mean that labor market institutions such as labor law, forms of employment, minimum wage, unemployment benefits, and labor taxation, operate less efficiently, avoid control, and create more space for unethical activities. These weaknesses can clearly be shown by the example of the National Labor Inspectorate (PIP). ${ }^{8}$

The weaknesses of the labor market, especially those related to violating ethical issues, lead to multiple economic, demographic, social, and political consequences. The main economic consequences include high and regionally differentiated unemployment rates, low consumer demand, a scarce and financially weak middle class, which is an important stimulator of technical progress, low income of the state budget due to low wages and forms of employment not provided by the Labor Code, and the low effectiveness of combating unemployment. The demographic consequences include economic emigration and a low fertility rate. Large social diversity and a lack of perspectives for young people are indicated as the main social consequences. The political consequences, on the other hand, are that society has become disappointed both with the market and with the state, which has resulted in an increase in the popularity of populist and nationalist slogans as well as the low turnout of young people in elections.

8 PIP's work should contribute to the improvement of the situation on the labor market; however, it is well-known that employees of this institution operate under the pressure of multiple restrictions. Among the most important, it is mentioned that: 1. National Labor Inspectorates have limited financial resources available (PLN 318 million in 2016) and personnel (about 1,600 inspectors who are very low paid, e.g., the pay of the junior inspector was PLN 2,500 gross and has been frozen since 2004); 2. PIP cannot perform unannounced inspections. The inspections take place at a time convenient for the employer and are arranged one week in advance; 3. Penalties for violating employee rights are low, so they do not deter people from breaking the law. It is often more profitable for employers to pay a penalty and include it in the company's operating costs; 4 . Inspectors can only carry out inspections in registered companies, so they cannot carry out inspections in companies operating in the gray area, where health and safety regulations are most often violated. 


\section{Conclusions}

The examples of non-compliance with ethical principles on the labor market indicate that they largely stem from the adopted model of the Polish systemic-liberal economic policy transformation (although - on the example of PGRs and hard coal mining - it can be seen that it has not been applied consistently), excessively making the labor market more flexible, weakening the position of trade unions, as well as weaknesses of other labor market institutions and the rapid development of the shadow economy. Under these conditions, it is difficult to expect the said weakness of the labor market to be effectively mitigated by referring to corporate social responsibility. If, after Joanna Filek (2006, p. 4), it is assumed that we can only speak about this responsibility if companies are doing something that goes beyond the legal norms in force, then we must also agree with the author (Filek 2007, p. 28) that we are only in the initial phase of its construction, "because the problem in our country involves compliance with applicable laws."

In this situation, Grażyna Wolska (2017) seems to be right when analyzing the ethical nature of the behavior of members of state institutions and businesses. She emphasizes that the changes should start from the highest state level. She justifies this as follows: "At this level, it has a large symbolic load, which can effectively stimulate changes, because the change at the highest level determines its rank and signals the importance of the problem."

Therefore, the current situation on the labor market requires changes. They should include:

1. Introducing legal solutions which strengthen the position of employees in their relations with employers and consistent compliance with these solutions, and especially increasing the role of trade unions in negotiations with the government and employers;

2. Changing the proportion of national income distribution in favor of employees, which requires changes in the system of taxation of income from work (in order to increase progressivity and redistributivity), as well as more consistent compliance with the Labor Code;

3. Undertaking a more consistent fight against the gray zone, which would increase the income of employees and the state budget. 


\section{References}

Baca-Pogorzelska, K. (2016), Jednak jest mafia weglowa, "Dziennik Gazeta Prawna”, 15-17.07.2016.

Botero, J.C., Djankov, S., La Porta, R., Lopez-de Silanes, F., Schleifer, A. (2003), The regulation of labour, NBER, "Working Paper”, No. 9756. https://doi.org/10.2139/ ssrn. 408480

Filek, J. (2006), Społeczna odpowiedzialność biznesu. Tylko moda czy nowy model prowadzenia działalności gospodarczej?, Urząd Ochrony Konkurencji i Konsumentów, Kraków.

Filek, J. (2007), Między wolnościa gospodarcza a odpowiedzialnościa społeczna biznesu, [in:] B. Klimczak, A. Lewicka-Strzelecka (eds.), Etyka i ekonomia, PTE, Warsaw.

Filipowicz, K., Tokarski, T., Włodarczyk, P. (2017), Taksonomiczne wskaźniki liberalizacji rynków pracy a zmiany zatrudnienia w wybranych krajach OECD, [in:] E. Kwiatkowski (ed.), Instytucje rynku pracy w krajach OECD. Istota, tendencje i znaczenie ekonomiczne, Wydawnictwo Uniwersytetu Łódzkiego, Łódź.

Gardowski, J. (2013), Czy działalność związków zawodowych ma sens? Związki na Powazkki, Michał Wybieralski talks with Juliusz Gardowski, “Gazeta Wyborcza”, 14-15.09.

Gasparski, W. (1999), Etyka biznesu, Wydawnictwo Naukowe PWN, Warsaw.

Gasparski, W., Lewicka-Strzałecka, A. (2001), Etyka biznesu jako przedmiot nauczania, Wydawnictwo Wyższej Szkoły Przedsiębiorczości i Zarządzania im. Leona Koźmińskiego, Warsaw.

Gasparski, W., Lewicka-Strzałecka, A., Rok, B., Szulewski, G. (2019), Europejskie i światowe standardy etyki oraz społecznej odpowiedzialności biznesu w działalności gospodarczej, www.edu.pl (accessed: 21.01.2019).

GUS (2018), Notatka informacyjna. Wybrane zagadnienia rynku pracy, 3.01.2018.

Kabaj, M. (2013), Mikroekonomiczne dylematy wynagradzania minimalnego, "Polityka Społeczna", No. 8.

Klimczak, A., Lewicka-Strzałecka, A. (ed.) (2007), Etyka i ekonomia, PTE, Warsaw.

Klimczak, B. (2006), Etyka gospodarcza, Akademia im. Oskara Langego, Wrocław.

Kowalik, T. (1996), Sierpień - epigońska rewolucja mieszczańska, "Nowe Życie Gospodarcze”, No. 37.

Kowalik, T. (2008), Czy kapitalizm może być etyczny?, “Annales. Etyka w życiu gospodarczym", Vol. 11, No. 1.

Krajewska, A. (2018), Płaca minimalna, PWE, Warsaw.

Kubiak, P., Kwiatkowski, E. (2017), Zasiłki dla bezrobotnych i ich wpływ na rynek pracy, [in:] E. Kwiatkowski (ed.), Instytucje rynku pracy w krajach OECD. Istota, tendencje i znaczenie ekonomiczne, Wydawnictwo Uniwersytetu Łódzkiego, Łódź.

Litwiński, J., Sztanderska, W., Giza-Poleszczuk, A. (2008), Rynki pracy na obszarach popegeerowskich. Raport z badań, Departament Analiz Ekonomicznych i Prognoz MPiPS, Warsaw.

Majchrowska, A. (2016), Wynagrodzenia $w$ Polsce na tle pozostałych państw Unii Europejskiej. Czy sq one relatywnie niskie i co zrobić aby przyśpieszyć ich wzrost? [in:] M. Bednarski (ed.), Wynagrodzenia w Polsce. Przesłanki i hamulce wzrostu, IPiSS, Warsaw. 
Nie zamordowałem pegeerów (2014), Krystyna Naszkowska talks with Adam Tański, "Gazeta Wyborcza" 28-29.06.

OECD (2015), Employment Outlook 2015, OECD, Library.

Prochownik, K., Rogowicz, M., Paletko, D. (2019), Etyka biznesu, https://mfiles.pl/pl/ index.php./Etyka_biznesu (accessed: 27.02.2019).

Statistical Yearbook GUS (1992), GUS Warsaw.

Statistical Yearbook GUS (1994), GUS Warsaw.

Statistical Yearbook of Labor, GUS, (2010, 2012, 2014, 2018), Warsaw.

Statistical Yearbook of the Republic of Poland (2015), GUS, Warsaw.

Statistical Yearbook of the Republic of Poland (2018), GUS, Warsaw.

Rozwadowska, A. (2018), Śmieciówki to norma w korpo, "Gazeta Wyborcza", 10 September.

Rutkowski, W. (2016), Makroekonomiczne konsekwencje wzrostu wynagrodzeń, [in:] M. Bednarski (ed.), Wynagrodzenia w Polsce. Przesłanki i hamulce wzrostu, IPiSS, Warsaw.

Schneider, F. (2009), Size and development of the shadow economy in Germany, Austria and other OECD countries: some preliminary findings, "Revue Économique" No. 60. https://doi.org/10.3917/reco.605.1079

Schneider, F. (2018), Implausible Large Differences of the Size of the Underground Economies in Highly Developed European Countries? A Comparison of Different Estimation Methods, http://www.econ.jku.at/t3/staff/schneider/papers/Haigner_Schneider_2018_Implausiblelargediff.pdf. (accessed: 11.05.2018)

Shadow Economies in the Baltic Sea Regions (2015), FOR, Warsaw.

Skidelsky, R. (2012), Keynes. Powrót Mistrza, Wydawnictwo Krytyki Politycznej, Warsaw.

Snower, D.J., (1997), Evaluating unemployment policies: what do the underlying theories tell us, [in:] D.J. Snower, G. de la Dehesa (ed.), Unemployment Policy: Government Option for the Labour Market, Cambridge 1997.

Stawrowski, Z. (2019), Czy państwo może być etyczne?, https://opoka.org.pl/biblioteka/F/FS/rec_etyczne_panstwo.html (accessed: 27.02.2019).

Szumlewicz, P. (2016), Wyzysk pracownika ma się dobrze, „Dziennik Gazeta Prawna”, 13-15 May.

Szumlewicz, P. (2018), Kiedy rząd przestanie wspierać śmieciówki, „Dziennik. Gazeta Prawna”, 17-19 August, No. 159 (9809).

Williamson, J. (1993), Democracy and the "Washington Consensus", Word Development, No. 21. https://doi.org/10.1016/0305-750X(93)90046-C

Wolska, G. (2017), Etyczność postępowania reprezentantów instytucji państwa i przedstawicieli biznesu, "Ruch Prawniczy, Ekonomiczny i Socjologiczny", Year LXXX - book 3. https://doi.org/10.14746/rpeis.2017.79.3.15

Wyrzykowski, W. (2013), Podatkowe uwarunkowania rozwoju przedsiębiorczości w Polsce, Politechnika Gdańska, Gdańsk. 


\section{Streszczenie}

\section{Rynek pracy w Polsce a społeczna odpowiedzialność państwa i biznesu. Aspekty porównawcze}

Na polskim rynku pracy pojawiło się wiele niepokojących zjawisk. W artykule zwrócono uwagę na kilka z nich, czyli: 1) niekonsekwencję w respektowaniu reguł mechanizmu rynkowego i dużą rolę decyzji politycznych, 2) utrzymywanie się przez długi okres wysokiej stopy bezrobocia i niską skuteczność metod walki z bezrobociem, 3) niski poziom płac i rosnące zróżnicowanie dochodów, 4) wysoki udział niestandardowych form zatrudnienia w zatrudnieniu ogółem. Skala tych niepokojących zjawisk jest większa niż w innych transformujących się gospodarkach.

W reakcji na niedoskonałości rynku pojawiło się w Polsce wiele publikacji dotyczących społecznej odpowiedzialności biznesu. Zdaniem autorów przyczyn omawianych w referacie mankamentów rynku pracy należy jednak poszukiwać nie tylko w nierespektowaniu zasad społecznej odpowiedzialności biznesu, ale także słabości przyjętych rozwiązań systemowych i słabości instytucji państwa.

Słowa kluczowe: rynek pracy, transformacja gospodarki, społeczna

odpowiedzialność biznesu 